\title{
Caries Preventive Effects of Theobromine Containing Toothpaste on Early Childhood Caries: Preliminary Results
}

\section{Karijesprotektivni učinak zubne paste koja sadržava teobromin na karijes u ranoj dječjoj dobi: preliminarni rezultati}

\footnotetext{
${ }^{1}$ Marmara University, Faculty of Dentistry, Department of Paediatric Dentistry, Istanbul, Turkey Zavod za pedodonciju Stomatološkog fakulteta Sveučilišta Marmara, Istanbul, Turska

2 Department of Paediatric Dentistry Bahcelievler Oral and Dental Health Hospital, Istanbul, Turkey

Zavod za pedodonciju Bolnice za oralno i dentalno zdravlje Bahcelievler, Istanbul, Turska
}

Received: September 16, 2020

Accepted: January 25, 2021

Address for correspondence Müesser Ahu DURHAN ORCID: 0000-0002-0605-1250 Marmara University Faculty of Dentistry Department of Paediatric Dentistry Maltepe, Basibuyuk Saglik Kampusu, 34854, Istanbul, Turkey Phon. 0090-5052451178 ahudurhan@hotmail.com

MeSH terms: Toothpastes; Theobromine; Tooth Remineralization; Preventive Dentistry; Preschool Child

\section{Introduction}

Dental caries is one of the most significant public health problems (1). Early childhood caries is a complex disease affecting children under 3 years of age. It is defined as the presence of one or more decayed (non- cavitated or cavitated lesions), missing (due to caries), or filled tooth surfaces. However, caries is particularly evident in upper central incisors (2). Caries affects primary teeth more often than permanent teeth because both enamel and dentin structures of primary teeth are thinner than those of permanent teeth. Also, children are fond of sweetened food and drinks. Additionally, the capability of oral hygiene maintenance in early stage of childhood is not satisfactory; therefore, deciduous teeth are more severely attacked by caries than permanent teeth (1).

Fluoride is an agent used extensively for the prevention of dental caries. The use of fluoride-containing toothpastes has been shown to be an effective way for children to prevent permanent teeth from tooth decay (3). It is also a wellknown fact that fluoride has a beneficial effect on slowing down the caries progression (4). While the use of fluoride is beneficial for strengthening the enamel, overexposure to flu-
Uvod

Zubni karijes jedan je od najvećih javnozdravstvenih problema (1). Karijes u ranoj dječjoj dobi složena je bolest koja pogađa djecu mlađu od tri godine. Definira se kao prisutnost jedne ili više površina zuba zahvaćenih karijesom (nekavitirana ili kavitirana lezija). Karijes uglavnom zahvaća gornje središnje sjekutiće (2). Zahvaća mliječne zube češće od trajnih jer je struktura cakline i dentina mliječnih zuba tanja nego kod trajnih. Djeca također vole zaslađenu hranu i piće. Uz to, u ranoj fazi djetinjstva nije zadovoljavajuća sposobnost održavanja oralne higijene i zato su mliječni zubi češće i teže zahvaćeni karijesom nego trajni (1).

Fluor je sredstvo koje se naširoko upotrebljava za prevenciju zubnog karijesa. Pokazalo se da je uporaba zubnih pasta koje sadržavaju fluor djelotvoran način za sprječavanje karijesa na trajnim zubima (3). Također je dobro poznata činjenica da fluor povoljno djeluje na usporavanje napredovanja karijesa (4). Iako je upotreba fluora dobra jer jača caklinu, ako se pretjerano primjenjuje pojavljuje se rizik od fluoroze. Povećan rizik od zubne i koštane fluoroze posljedica je gutanja fluora iz različitih izvora te gutanja zubne paste s fluorom (5). 
oride carries the risk of fluorosis. An increased risk of dental and skeletal fluorosis is due to the ingestion of fluoride from different sources and from swallowing toothpaste with fluoride (5). Additionally, it has been disputed whether fluorides interact with ameloblasts, thus having adverse effects on the enamel formation (6).

In recent years, different biomimetic agents have been discussed as potential alternatives to fluoride for the prevention of ECC. Some studies showed that it is best to use toothpastes that mainly contain remineralizing agents for children's oral care such as calcium phosphates, that is, CPP-ACP or hydroxyapatite (HAP), (7). A variety of agents containing different calcium phosphate compounds that have already been on the market have been well studied (8). Previous in vitro and in vivo studies suggested that crystallite size was increased and crystallinity of teeth improved by growing HAP in an apatite-forming system. Therefore, toothpaste containing synthetic hydroxyapatite crystals has been developed to improve remineralization on the basis of structural similarity of the crystals to those contained in human teeth.

Another promising alternative, theobromine, was discovered accidentally during studies of dental caries. Consumption of chocolate as a sugar-containing confectionery has long been linked to dental caries (9). However, a series of studies demonstrated that cocoa powder in chocolate by itself might have some caries-inhibitory effect (10-14). Studies with hamsters showed that pure cocoa powder inhibited dental caries in correlation with the percentage consumed in diet, and that reduced fat cocoa exhibited a higher significant anticaries effect than the fat-containing cocoa (12).

Cocoa solids also contain both theobromine and caffeine. While studying the effect of cocoa on the mineralization of teeth, it was discovered that cocoa has both demineralizing and remineralizing effects because of the coexistence of theobromine and caffeine. On one hand, caffeine reduces the crystal size on the enamel surface when children are exposed to caffeine at a critical growth period (15). In a study conducted to investigate the effect of caffeine on crystallization of enamel and formation of caries, it was observed that rats exposed to caffeine had a significantly higher caries score when compared to the decaffeinated control group (16). Caffeine reduced crystallization of the enamel and a smaller crystal size increased dissolution of the minerals leading to dental carries (17). Along with caffeine, cocoa contains substantial amounts of polyphenolic substances, such as tannin and chlorogenic acid, which tend to produce darker colors (18). Therefore, recognizing and investigating the products that can be applied to teeth to decrease the absorption of demineralizing substances and to reduce discoloration of the teeth is important. On the other hand, theobromine was shown to have an entirely opposite effect, by enhancing crystallinity of enamel $(19,20)$, binding calcium and phosphate to remineralize the tooth enamel ${ }^{21}$. Theobromine is a naturally occurring substance, making it a potential alternative to fluoride as the active ingredient of toothpaste $(21,22)$. It is the principle alkaloid from the family of methylxanthines, which also includes theophylline and caffeine, and the main source is Theobroma cacao (cacao tree) plant (23). When add-
No sporno je djeluje li fluor na ameloblaste čime štetno djeluje na stvaranje cakline (6).

Posljednjih se godina raspravljalo o različitim biomimetičkim agensima kao o potencijalnim alternativama fluoru za prevenciju karijesa u ranom djetinjstvu. U nekim istraživanjima autori su istaknuli da je najbolje upotrebljavati zubne paste koje uglavnom sadržavaju remineralizirajuća sredstva za oralnu higijenu kod djece, poput kalcijeva fosfata, odnosno CPP-ACP-a ili hidroksiapatita (HAP) (7). Različiti agensi koji sadržavaju različite spojeve kalcijeva fosfata dobro su proučeni (8). U dosadašnjim istraživanjima in vitro i in vivo pokazano je da se veličina kristalita povećava, a kristalnost zuba poboljšava rastom HAP-a u sustavu koji stvara apatit. Zato je proizvedena zubna pasta sa sintetičkim kristalima hidroksiapatita radi poboljšanja remineralizacije na temelju strukturne sličnosti kristala s onima u ljudskim zubima.

Druga obećavajuća alternativa - teobromin, otkrivena je slučajno tijekom istraživanja zubnog karijesa. Konzumacija čokolade kao slastice koja sadržava šećer odavno je povezana s pojavom karijesa (9). No u nizu istraživanja istaknuto je da kakao u prahu u čokoladi može inhibicijski djelovati na karijes $(10$ - 14). Istraživanja na hrčcima pokazala su da čisti kakao u prahu inhibira zubni karijes u korelaciji s postotkom konzumiranja u prehrani te da kakao sa smanjenim udjelom masti ima značajniji protukarijesni učinak od onoga koji sadržava masti (12).

Čvrsti sastojci kakaa sadržavaju i teobromin i kofein. Tijekom proučavanja učinka kakaa na mineralizaciju zuba otkriveno je da i demineralizirajuće i remineralizirajuće djeluje zbog koegzistencije teobromina i kofeina. $S$ jedne strane, kofein smanjuje veličinu kristala na površini cakline kada su mu djeca izložena u kritičnom razdoblju rasta (15). U istraživanju o učinku kofeina na kristalizaciju cakline i stvaranje karijesa uočeno je da su štakori izloženi kofeinu imali znatno češce karijes u usporedbi s kontrolnom skupinom bez kofeina (16). Kofein smanjuje kristalizaciju cakline, a manja veličina kristala povećava otapanje minerala što potiče zubni karijes (17). Osim kofeina kakao sadržava znatnu količinu polifenolnih tvari, poput tanina i klorogenske kiseline koje imaju sklonost prema stvaranju tamnijih boja (18). Zato je važno prepoznati i istražiti proizvode koji se mogu primijeniti na zube kako bi se smanjila apsorpcija demineralizirajućih tvari i smanjila promjena njihove boje. $S$ druge strane pokazalo se da teobromin ima potpuno suprotan učinak jer povećava kristalnost cakline $(19,20)$ te veže kalcij i fosfat i tako remineralizira i zubnu caklinu (21). Teobromin je tvar koja se pojavljuje u prirodi, što je čini potencijalnom alternativom fluoru kao aktivnom sastojku zubne paste $(21,22)$. Glavni je alkaloid iz obitelji metilksantina koja također uključuje teofilin i kofein, a glavni izvor je biljka Theobroma cacao (drvo kakaovca) (23). Kada se doda zubnim pastama, štiti površinu cakline u pozitivnom odnosu doza - odgovor (24). U mnogim istraživanjima in vitro i nekima in vivo istaknuto je da primjena teobromina može rezultirati remineralizacijom i prevencijom površinskog karijesa u caklini. No prema našim spoznajama ni u jednom istraživanju autori se nisu bavili učinkom na dječje zube sredstava za oralnu higijenu koja sadržavaju teobromin. 
ed to dentifrices, it protects the enamel surface of the tooth in a positive dose-response relationship (24). A large number of in-vitro and some in-vivo studies, from the literature, demonstrated that the application of theobromine can result in remineralization and prevention of surface caries in enamel. However, to the best of our knowledge, no study investigated the effects of theobromine containing dentifrices on children.

The purpose of this study was to evaluate the efficacy of theobromine containing toothpaste (THEODENT Kids) on remineralization of white spot lesions, short term effect on $S$. mutans, buffering capacity and $\mathrm{pH}$ of saliva in children with ECC. The null hypothesis to be tested was that no statistically significant difference exists between the fluoride containing toothpaste group and theobromine containing toothpaste group.

\section{Material and methods}

The study was reviewed and approved by The Human Research Ethics Committee of Yeditepe University, School of Medicine on January 07, 2014 with the protocol number of 392.

The power was set at $80 \%$, alfa-level was set as 0.05 , and the allocation ratio was equal to 1 . The study was conducted with a total of 26 children between the ages of 4-5 presented with ECC who were equally assigned at random to the two study groups. None of the baseline values showed statistical differences among the groups. The parents completed a general health questionnaire form and gave informed consent on behalf of their children to participate in the study. Based on the completed questionnaires, the subjects were assessed for eligibility to undergo the baseline clinical evaluation. The children who had one or more white spot lesions were included to the study. The children with systemic medical conditions, history of prolonged use of antibiotics or medication were not included. The children who were not able to cooperate in the course of clinical examination were excluded from the study.

\section{Clinical evaluation}

Oral examination of children was performed under the standard dental operatory light. The surfaces of the teeth were cleaned thoroughly with water, and later air dried with a three-way syringe for 10 seconds. Children were randomly allocated to 2 groups: a control group with 13 children to use a 500 ppm Fluoridated toothpaste (Colgate Kids, Colgate-Palmolive Company, NY) and a test group of 13 children to use a theobromine containing toothpaste (THEODENT Kids, New Orleans) (Table 1). Oral health education was provided to both groups to improve their knowledge, attitude, and practice regarding oral health. Toothpastes were delivered to the parents and they were informed to encourage the children to brush their teeth with the assigned toothpastes two times a day for 1 month.

\section{Scoring using Laser Fluorescence (LF)}

A trained and calibrated pediatric dentist performed the clinical examinations. After calibration with a ceramic standard, the baseline value for each individual was calibrated by
Svrha ovog istraživanja bila je procijeniti učinkovitost paste za zube $s$ teobrominom (THEODENT Kids) na remineralizaciju bijelih mrlja, kratkoročni učinak na $S$. mutans, puferski kapacitet i $\mathrm{pH}$ sline djece $s$ karijesom u ranoj dobi. Nulta hipoteza koju je trebalo ispitati bila je da ne postoji statistički značajna razlika između pasta za zube koje sadržavaju fluor i teobromin.

\section{Materijali i metode}

Istraživanje je provjerilo i odobrilo 7. siječnja 2014. godine Etičko povjerenstvo za ljudska istraživanja Medicinskog fakulteta Sveučilišta Yeditepe (protokol 392).

Snaga je postavljena na $80 \%$, alfa na 0,05 , a omjer raspodjele bio je jednak 1 . U istraživanju je sudjelovalo ukupno 26 djece u dobi od 4 do 5 godina s karijesom rane dječje dobi te su nasumce raspoređeni u dvije skupine. Nijedna od osnovnih vrijednosti nije pokazala statističke razlike među skupinama. Roditelji su ispunili formular o općem zdravlju i potpisali informirani pristanak uime svoje djece za sudjelovanje u istraživanju. Na temelju popunjenih upitnika procijenjeno je mogu li uspješno proći osnovnu kliničku procjenu. U istraživanje su bila uključena djeca s jednom ili više bijelih lezija. Djeca sa sistemskim bolestima, anamnezom produljene upotrebe antibiotika ili lijekova nisu bila uključena. Djeca koja nisu mogla surađivati tijekom kliničkog pregleda bila su isključena iz istraživanja.

\section{Klinički pregled}

Klinički pregled djece obavljen je pod standardnim operacijskim osvjetljenjem. Površine zuba temeljito su očišćene vodom, a zatim osušene ispuhivanjem 10 sekunda. Djeca su nasumce raspoređena $\mathrm{u}$ dvije skupine - $\mathrm{u}$ kontrolnu skupinu od 13 djece koja su upotrebljavala zubnu pastu s 500 ppm fluora (Colgate Kids, Colgate-Palmolive Company, NY, SAD) i testnu skupinu od 13 djece koja su se koristila zubnom pastom koja je sadržavala teobromin (THEODENT Kids, New Orleans, SAD) (tablica 1.). U objema skupinama održana je edukacija o oralnom zdravlju da bi se poboljšali znanje, stajalište i praksa u vezi s njegovim očuvanjem. Paste za zube dobili su roditelji, uz upute da potiču djecu da mjesec dana peru zube dodijeljenim pastama dva puta na dan.

\section{Evaluacija s pomoću laserske fluorescencije (LF)}

Kliničke preglede obavio je educirani i kalibrirani dječji stomatolog. Nakon kalibracije s keramičkim standardom, bazna vrijednost za svakog pojedinca kalibrirana je mjerenjem 


\begin{tabular}{|c|c|c|}
\hline & Active Ingredients $\bullet$ Aktivni sastojci & Inactive Ingredients $\bullet$ Neaktivni sastojci \\
\hline $\begin{array}{l}\text { Colgate Kids, } \\
\text { Colgate-Palmolive } \\
\text { Company }\end{array}$ & $\begin{array}{l}\text { Sodium Fluoride }(0.05 \% \mathrm{w} / \mathrm{v} \text { Fluoride } \\
\text { Ion) • Natrijev fluorid }(0,05 \% \mathrm{w} / \mathrm{v} \\
\text { fluoridnih iona) }\end{array}$ & $\begin{array}{l}\text { Sorbitol } \\
\text { Water } \bullet \text { Voda } \\
\text { Hydrated Cilica } \bullet \text { Hidratizirana cilica } \\
\text { PEG-12 } \\
\text { Cellulose Gum } \bullet \text { Celulozna guma } \\
\text { Sodium Lauryl Sulfate } \bullet \text { Natrijev lauril-sulfat } \\
\text { Flavor } \bullet \text { Okus } \\
\text { Sodium Saccharin } \bullet \text { Natrijev saharin } \\
\text { Mica } \\
\text { Blue } 1 \cdot \text { Plava } 1 \\
\text { Titanium Dioxide } \bullet \text { Titanijev dioksid }\end{array}$ \\
\hline $\begin{array}{l}\text { THEODENT Kids, } \\
\text { New Orleans }\end{array}$ & $\begin{array}{l}\text { Rennou: theobromine, calcium acetate, } \\
\& \text { sodium hydrogen phosphate } \\
\text { teobromin, kalcijev acetat i natrijev } \\
\text { hidrogen-fosfat }\end{array}$ & $\begin{array}{l}\text { purified water } \bullet \text { pročišćcna voda } \\
\text { hydrated silica } \bullet \text { hidratirani silicijev dioksid } \\
\text { sorbitol, xylitol, (plant based) } \bullet \text { sorbitol, ksilitol (na biljnoj bazi) } \\
\text { glycerin, xanthan gum } \bullet \text { glicerin, ksantanska guma } \\
\text { titanium dioxide (non-nano particle form) } \bullet \text { titanijev dioksid (nenanočestice) } \\
\text { citric acid } \bullet \text { limunska kiselina } \\
\text { sodium benzoate } \bullet \text { natrijev benzoat } \\
\text { stevia extract } \bullet \text { ekstrakt stevije } \\
\text { sodium bicarbonate } \bullet \text { natrijev bikarbonat } \\
\text { sugar-free chocolate extract } \bullet \text { ekstrakt čokolade bez šećera } \\
\text { sugar-free vanilla extract } \bullet \text { ekstrakt vanilije bez šećera }\end{array}$ \\
\hline
\end{tabular}

measuring which was performed on the sound buccal surface of the tooth. A single examiner made all measurements for 3 times to eliminate the operator effect for each lesion, and the operator was blinded to intervention.

White spot lesions (WSLs) were categorized according to the International Caries Detection and Assessment System (ICDAS II; codes 0-3). (0: sound ;1: first visual changes in enamel; 2: distinct visual changes in enamel; 3: Localized enamel breakdown (without clinical signs of dentinal involvement), (25).

A portable LF system (DIAGNODent (DD) pen, KaVo, Biberach, Germany) was used. Standard DD recordings were taken at this stage according to the manufacturer's instructions. The depths of demineralization were subjected using LF threshold. The manufacturer suggested the presence and depth of a caries lesion at the occlusal surfaces by LF using the following scale: $0-13=$ initial caries lesion; $14-20=$ enamel caries; $21-30=$ initial dentine caries; $31-99=$ advanced dentine caries (26).

The status of WSLs was assessed using LF at 4 weeks recall and the changes in the amount of the values were recorded.

\section{Testing Saliva $\mathrm{pH}$ and Buffering Capacity}

Saliva samples were also used to assess buffering capacity utilizing the Saliva-Check Buffer test kit (GC Corporation, Tokyo; Japan). The test started at least 2 hours after the last meal and at least 1 hour after brushing of the teeth. Saliva was stimulated by paraffin wax, and then saliva samples were used to measure salivary $\mathrm{pH}$ and its buffering capacity. Patients were instructed to spit any pooled saliva into the collection cup. After this procedure, an enclosed $\mathrm{pH}$ strip was placed into the sample of collected saliva for 10 seconds. Color change on the $\mathrm{pH}$ strip was checked while the paper was still moist. The $\mathrm{pH}$ reading was noted and the results were re- koje je obavljeno na zdravoj bukalnoj površini zuba. Jedan istraživač proveo je sva mjerenja tri puta za svaku leziju.

Bijele mrlje kategorizirane su prema Međunarodnom sustavu za otkrivanje i procjenu karijesa (ICDAS II; oznake 0 - 3). (0 - zdravo; 1 - prve vizualne promjene na caklini; 2 - izrazite vizualne promjene na caklini; 3 - lokalizirano urušavanje cakline (bez kliničkih znakova zahvaćenosti dentina) (25).

Korišten je prijenosni LF sustav (DIAGNODent (DD) pen, KaVo, Biberach, Njemačka). Standardna DD mjerenja provedena su u toj fazi prema uputama proizvođača. Dubine demineralizacije ocijenjene su primjenom LF praga. Proizvođač je predložio sljedeće bodovanje prisutnosti i dubine karijesne lezije na okluzalnim površinama s pomoću LF-a: 0 - 13 = početna karijesna lezija; $14-20=$ karijes cakline; 21 $-30=$ početni karijes dentina; $31-99=$ napredovali karijes dentina (26).

Status bijelih mrlja procijenjen je korištenjem LF-a na kontrolnom pregledu nakon četiri tjedna i zabilježene su promjene ranije dobivenih vrijednosti.

\section{Mjerenje pH i puferskoga kapaciteta sline}

Uzorci sline također su korišteni za procjenu puferskoga kapaciteta s pomoću seta Saliva Check Buffer Test (GC Corporation, Tokio, Japan). Test je proveden najmanje dva sata poslije zadnjeg obroka i najmanje jedan sat nakon pranja zuba. Slina je stimulirana parafinskim voskom, a zatim su uzorci upotrijebljeni za mjerenje njezina $\mathrm{pH}$ i puferskoga kapaciteta. Pacijentima je naloženo da ispljunu slinu u šalicu za skupljanje. Nakon toga postupka, $\mathrm{pH}$ vrpca stavljena je 10 sekunda u uzorak skupljene sline. Promjena boje vrpci provjerena je dok je papir još bio vlažan. Očitana je $\mathrm{pH}$ vrijednost i rezultati su zabilježeni kao 5,0 do 5,8 (vrlo kiselo); 6,0 
corded as 5.0- 5.8 (high acidic); 6.0-6.6 (moderately acidic) and 6.8-7.8 (healthy saliva).

5 minute stimulated saliva was used to assess buffering capacity. After that, the test pads color changes were evaluated as green 4; green/blue 3; blue 2; Red/Blue 1 and Red 0 points according to the manufacturer's instructions.

\section{Testing Saliva Streptococcus mutans}

The salivary samples were checked for $S$. mutans count by GC Saliva-Check Mutans ${ }^{\mathrm{TM}}$ test kit (GC Corporation, Tokyo; Japan). Stimulated saliva was tested to measure $S$. mutans levels at baseline. Technique guidelines were followed according to manufacturer's instructions to detect $S$. mutans in saliva via a highly accurate and specific immunochromatography process by employing monoclonal antibodies (MAbs) which can detect small numbers of $S$. mutans in small salivary samples. A positive result was obtained if a thin red line appeared in the T window high levels of $S$. mutans $\left(>5 \times 10^{5} \mathrm{CFU} / \mathrm{mL}\right)$; however, if no line appeared (negative result), it indicated low levels of $S$. mutans (<5X $\left.10^{5} \mathrm{CFU} / \mathrm{mL}\right)$. Saliva collection for testing was done at the same time of day for the children.

Statistical analyses were performed using SPSS Statistics Version 19.0 (SPSS Inc., Chicago, IL, USA). In-group comparisons to determine the extent of remineralization was done using the paired t-test. In order to perform between-group comparisons, the difference of means (mean of pre-treatment values minus mean of post-treatment values) for each group was calculated. Between-group comparisons for the difference of means were done using the Mann Whitney U Test. For all the statistical analyses, the significance level was set at $<0.05$.

\section{Results}

We included 13 healthy children with mean age $4.25 \pm 0.50$ with 145 teeth in the fluoride toothpaste group as the control group, and 13 healthy children with mean age $4.46 \pm 0.52$ with 115 teeth in theobromine containing toothpaste group as the test group. After 1-month of experimental period, 26 children with a total of 260 study teeth (13 children, 145 teeth in control group; 13 children, 115 teeth in theobromine containing toothpaste group) were re-examined.

\section{Laser Fluorescence (LF)}

The mean $L F$ reading was $20.71 \pm 1.50$ in the control group and $14.60 \pm 1.66$ in the theobromine containing toothpaste group at baseline, which decreased to $17.00 \pm 1.27$ and $9.75 \pm 1.16$, respectively at 1 -month follow-up visit. The do 6,6 (umjereno kiselo) i 6,8 do 7,8 (zdrava slina).

Za procjenu puferskoga kapaciteta upotrijebljena je slina koja je stimulirana pet minuta. Nakon toga su promjene boje testnih pločica ocijenjene prema uputama proizvođača kao zelena -4 boda; zelena/plava -3 ; plava -2 ; crveno/plava -1 i crvena - 0 bodova.

\section{Mjerenje razine salivarne bakterije Streptococcus mutans}

U uzorcima sline provjerena je razina $S$. mutans s pomoću seta GC Saliva-Check Mutans ${ }^{\mathrm{TM}}$ (GC Corporation, Tokio, Japan). Stimulirana slina upotrijebljena je za mjerenje razine S. mutans na početku. Postupak je proveden prema uputama proizvođača za otkrivanje te bakterije u slini vrlo preciznom i specifičnom metodom imunokromatografije primjenom monoklonskih antitijela (MAbs) koja mogu otkriti mali broj $S$. mutans u malim uzorcima sline. Pozitivan rezultat dobiva se ako se u T-prozorčiću pojavi tanka crvena crta, što označuje visoku razinu $S$. mutans (> $5 \mathrm{X} 105 \mathrm{CFU} / \mathrm{ml}$ ). Ako se crta nije pojavila (negativan rezultat), to upućuje na nisku razinu te bakterije (<5 X $105 \mathrm{CFU} / \mathrm{mL}$ ). Slina za testiranje od djece se skupljala u isto doba dana.

Statističke analize provedene su u programu SPSS Statistics Version 19.0 (SPSS Inc., Chicago, IL, SAD). Usporedbe u skupinama radi utvrdivanja opsega remineralizacije obavljene su uparenim t-testom. Za usporedbe među skupinama izračunata je razlika srednjih vrijednosti (srednja vrijednost prije liječenja umanjena za vrijednost vrijednosti poslije obrade) za svaku skupinu. Usporedbe razlika srednjih vrijednosti među skupinama provedene su Mann-Whitneyevim U-testom. Za sve statističke analize razina značajnosti postavljena je na $<0,05$.

\section{Rezultati}

U kontrolnu skupinu s fluoriranom zubnom pastom bilo je uključeno 13 zdrave djece prosječne dobi $4,25 \pm 0,50$ sa 145 zuba, a u testnu skupinu s teobrominom 13 zdrave djece srednje dobi 4,46 $\pm 0,52$ sa 115 zuba. Nakon jednomjesečnog eksperimentalnog razdoblja ponovno je pregledano 26 djece $s$ ukupno 260 proučavanih zuba (13 djece, 145 zuba u kontrolnoj skupini; 13 djece, 115 zuba u skupini koja sadržava zubnu pastu s teobrominom).

\section{Laserska fluorescencija (LF)}

Prosječno očitanje LF-a iznosilo je $20,71 \pm 1,50$ u kontrolnoj skupini i $14,60 \pm 1,66$ u skupini djece koja su se koristila zubnom pastom $s$ teobrominom na početku, što se smanjilo na $17,00 \pm 1,27$, odnosno $9,75 \pm 1,16$, na prvom

\begin{tabular}{|c|c|c|c|c|c|}
\hline $\begin{array}{l}\text { Change DIAGNOdent values • } \\
\text { Promjena DIAGNOdent vrijednosti }\end{array}$ & $\mathbf{N}$ & $\begin{array}{c}\text { Mean }(\mathrm{SE}) \bullet \\
\text { Srednja vrijednost }(\mathrm{SP})\end{array}$ & $\begin{array}{l}\text { Mean Difference • } \\
\text { Srednja razlika }\end{array}$ & $\mathrm{t}$ value $\bullet t$ vrijednost & $P$ value $\bullet P$ vrijednost \\
\hline $\begin{array}{l}\text { Fluoride toothpastes } \\
\text { Zubna pasta s fluorom }\end{array}$ & 170 & $3.71 \pm 0.82$ & \multirow{2}{*}{1.22} & \multirow{2}{*}{0.967} & \multirow{2}{*}{0.339} \\
\hline $\begin{array}{l}\text { Theodent }{ }^{\mathrm{TM}} \text { Kids Toothpaste } \bullet \\
\text { Theodent }{ }^{\mathrm{TM}} \text { Kids zubna pasta }\end{array}$ & 115 & $4.93 \pm 0.97$ & & & \\
\hline
\end{tabular}




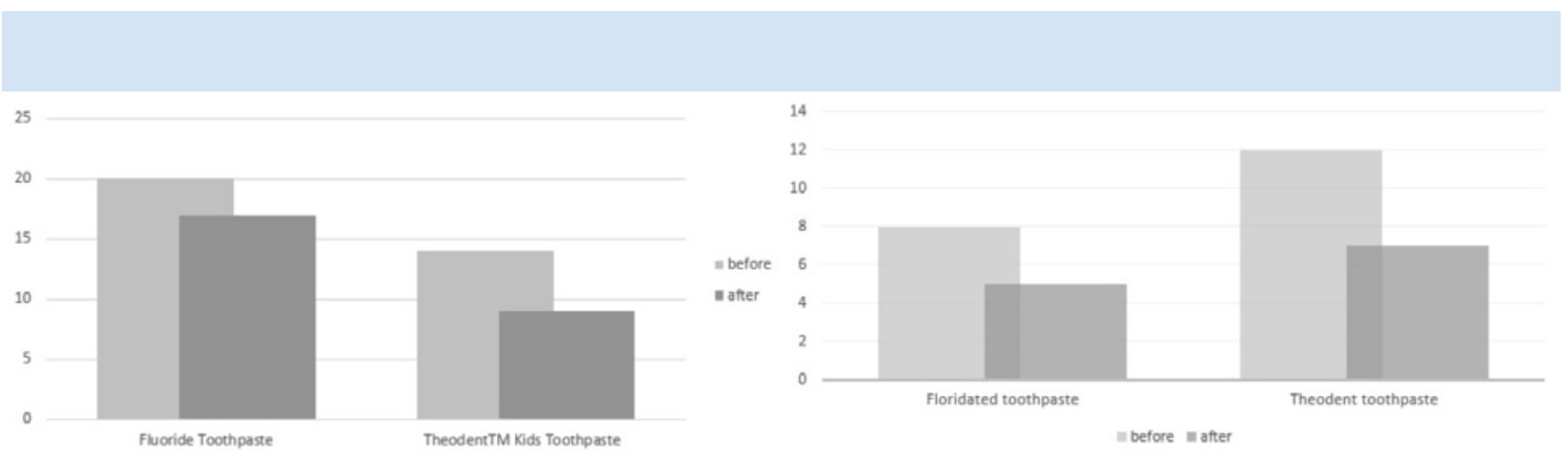

Figure $1 \mathrm{LF}$ values before and after using Fluoride toothpaste and Theobromine containing Toothpaste

Slika 1. LF vrijednosti prije i poslije primjene zubne paste $s$ fluorom ili teobrominom
Figure 2 The frequency of Saliva S. mutans before and after interventions

Slika 2. Razina salivarnog S. mutans prije i poslije tretiranja use of both of the toothpastes showed a highly significant $(p<0.0001)$ remineralizing potential at the end of treatment period of 1-month (Figure 1). The remineralizing potential of fluoride containing toothpaste was not significantly higher than that of theobromine containing toothpaste with the mean difference in pre- and post-intervention readings being only $1.22(p=0.339)$ (Table 2$)$.

\section{Salivary pH / buffering capacity}

There was a significant increase between the baseline and 1 -month readings of the salivary $\mathrm{pH}$ measurements in Theobromine containing Toothpaste $(p=0.013)$ group, compared to the Fluoride containing toothpaste group $(\mathrm{p}=0.222)$

A statistically significant increase in salivary buffering capacity was detected with the use of both toothpastes, Fluoride Toothpaste and Theobromine containing Toothpaste respectively ( $p=0.003$ and $p<0.0001)$ (Table 3$)$. mjesečnom kontrolnom pregledu. Upotreba obiju zubnih pasta pokazala je vrlo značajan $(\mathrm{p}<0,0001)$ potencijal remineralizacije na kraju razdoblja liječenja od jednog mjeseca (slika 1.). Potencijal remineralizacije zubne paste koja sadržava fluor nije bio značajno veći od potencijala zubne paste s teobrominom, a srednja razlika u očitanjima prije intervencije i poslije nje iznosila je samo $1,22(\mathrm{p}=0,339)$ (tablica 2.).

\section{Salivarni pH/puferski kapacitet}

Zabilježen je značajan porast između početnoga i jednomjesečnoga očitanja $\mathrm{pH}$ vrijednosti sline $\mathrm{u}$ skupini sa zubnom pastom koja sadržava teobromin $(p=0,013)$ u odnosu prema skupini sa zubnom pastom s fluorom $(\mathrm{p}=0,222)$

Statistički značajan porast puferskoga kapaciteta sline zabilježen je nakon primjene obiju pasta za zube - $\mathrm{i}$ paste $s$ fluorom i paste $s$ teobrominom $(\mathrm{p}=0,003 \mathrm{i} \mathrm{p}<0,0001)$ (tablica 3.).

\begin{tabular}{|c|c|c|c|}
\hline & & $\begin{array}{l}\text { Fluoride Toothpaste } \bullet \\
\text { Zubna pasta } s \text { fluorom } \\
n=13 \\
\text { mean }(\mathrm{SE}) \bullet \text { sredina }(\mathrm{SP})\end{array}$ & $\begin{array}{c}\text { Theodent }^{\mathrm{TM}} \text { Kids Toothpaste } \\
\mathrm{n}=13 \\
\text { mean }(\mathrm{SE}) \bullet \text { sredina }(\mathrm{SP})\end{array}$ \\
\hline \multirow{3}{*}{ Saliva $\mathrm{pH} \bullet$ Salivarni $\mathrm{pH}$} & baseline $\bullet$ prije & $7.08 \pm 0.40$ & $6.83 \pm 0.44$ \\
\hline & after $\bullet$ poslije & $7.22 \pm 0.43$ & $7.17 \pm 0.43$ \\
\hline & $\mathrm{p}$ & 0.222 & 0.013 \\
\hline \multirow{3}{*}{$\begin{array}{l}\text { Saliva buffer • Salivarni } \\
\text { puferski kapacitet }\end{array}$} & before $\bullet$ prije & $7.08 \pm 0.61$ & $6.85 \pm 0.49$ \\
\hline & after $\bullet$ poslije & $9.46 \pm 0.62$ & $9.69 \pm 0.53$ \\
\hline & $\mathrm{p}$ & 0.003 & 0.000 \\
\hline
\end{tabular}

Table 4 Intergroup comparison of saliva $\mathrm{pH}$ and Saliva Buffer

Tablica 4. Usporedba pH i puferskoga kapaciteta sline među skupinama

\begin{tabular}{|c|c|c|c|c|c|}
\hline & $\begin{array}{c}\text { Fluoride Toothpaste } \\
\text { Zubna pasta } s \text { fluorom } \\
n=13 \\
\text { mean }(\mathrm{SE}) \bullet \begin{array}{c}\text { srednja vrijednost } \\
(\mathrm{SP})\end{array}\end{array}$ & $\begin{array}{c}\text { Theodent }{ }^{\mathrm{TM}} \text { Kids Toothpaste } \\
\mathrm{n}=13 \\
\text { mean }(\mathrm{SE}) \bullet \begin{array}{c}\text { srednja vrijednost } \\
(\mathrm{SP})\end{array}\end{array}$ & $\begin{array}{c}\text { Mean Difference } \\
\text { srednja razlika }\end{array}$ & $\begin{array}{l}t \text { value } \\
t \text { vrijednost }\end{array}$ & $\begin{array}{l}\text { P value • } \\
\text { P vrijednost }\end{array}$ \\
\hline Saliva $\mathrm{pH} \bullet$ Salivarni $\mathrm{pH}$ & $0.15 \pm 0.11$ & $0.33 \pm 0.12$ & 0.19 & 1.18 & 0.248 \\
\hline $\begin{array}{l}\text { Saliva buffer } \bullet \text { Salivarni } \\
\text { puferski kapacitet }\end{array}$ & $2.38 \pm 0.65$ & $2.38 \pm 0.65$ & 0.46 & 0.57 & 0.571 \\
\hline
\end{tabular}


Saliva $\mathrm{pH}$ and buffer changes of the subjects in the fluoride toothpaste assigned group showed no difference from those of Theobromine containing Toothpaste assigned group, with the mean difference at the baseline and after intervention being only 0.19 and 0.46 respectively $(p=0.248, p=$ 0.571) (Table 4).

\section{Microbiological analysis}

The frequency of $S$. mutans was $8 / 13$ at the baseline and decreased to $5 / 13$ after using fluoride containing toothpaste for a month. The changes of frequency of $S$. mutans were 62.5 $\%$. In the theobromine containing toothpaste group, the frequency of $S$. mutans was $12 / 13$ at the baseline and it decreased to $7 / 13$ after using toothpaste for a month. The changes of the frequency of S. mutans were $58.33 \%$. These changes were not found to be statistically significant in both the Fluoride and the Theobromine toothpaste groups ( $p>0.05)$ (Figure 2).

\section{Discussion}

The observation of a significant net remineralization has revealed that the treatment modalities in this study, theobromine and sodium fluoride $(\mathrm{NaF})$, enhanced the resistance of the remineralized surface to subsequent acid challenge. Therefore, remineralization generated by the use of theobromine as a remineralizing agent demonstrated an increase in resistance of the enamel crystals to further acid attacks (27).

Amaechi BT. et al investigated the effects of both theobromine and $\mathrm{NaF}$ containing toothpastes. The surface microhardness showed a significant remineralization only when theobromine toothpaste was used. Although it exhibited comparable levels of remineralization on molar level, the amount of theobromine $(0.0011 \mathrm{~mol} / \mathrm{l})$ required to produce a cariostatic effect was 71 times smaller than that of fluoride $(0.0789 \mathrm{~mol} / \mathrm{l})$ to produce a comparable effect in theobromine and $\mathrm{NaF}$ containing toothpastes. They concluded that theobromine has a remineralization enhancing effect due to its ability to formation of apatite in comparison with the $\mathrm{NaF}$ containing toothpastes (28).

Lippert F. (2017) investigated the effects of fluoride, strontium, theobromine and their combinations on caries lesion remineralization under $\mathrm{pH}$ cycling conditions (29).

Kargül et al. observed the effect of theobromine in preserving the enamel surface in their study as well. The objective of this in-vitro study was to investigate the efficacy of theobromine treatment on the surface hardness and topography of human enamel at two different concentrations. The analyses of the microhardness of the enamel surface values at the baseline and after treatment with theobromine showed the protective effect of theobromine treatment (24). Further investigations using human teeth were conducted to evaluate how theobromine exposure modified the enamel surface in vitro $(24,28,30)$. By supporting the findings in the in-vitro study, the results of the in-vivo study have shown that the microhardness of the enamel surface of the theobromine group was greatly enhanced compared to the fluoride group (28).

Qasthari A.I. et. al. (2018) showed that theobromine containing toothpastes maintained the enamel surface roughness better than sodium monofluorophosphate toothpastes (31).
Promjene $\mathrm{pH}$ i puferskoga kapaciteta sline kod ispitanika u skupini s fluoriranom zubnom pastom nisu pokazale nikakvu razliku u odnosu prema onima u skupini s pastom koja je sadržavala teobromin (tablica 4.).

\section{Mikrobiološka analiza}

Razina bakterije $S$. mutans bila je $8 / 13$ na početku i smanjila se na 5/13 nakon jednomjesečne upotrebe paste za zube koja sadržava fluor. Promjena razine $S$. mutans iznosila je $62,5 \%$. U skupni sa zubnom pastom $s$ teobrominom razina $S$. mutans bila je $12 / 13$ na početku, a smanjila se na $7 / 13$ nakon mjesec dana korištenja te zubne paste. Promjena razine $S$. mutans iznosila je 58,33 \%. Te promjene nisu bile statistički značajne ni u skupini s fluorom, ni s teobrominom (p $>0,05)$ (slika 2.).

\section{Rasprava}

Pojava značajne neto remineralizacije otkrila je da su aktivne tvari u ovom istraživanju - teobromin i natrijev fluorid $(\mathrm{NaF})$, povećale otpor remineralizirane površine na naknadno djelovanje kiseline. Zato je remineralizacija generirana upotrebom teobromina kao remineralizirajućeg agensa rezultirala povećanjem otpornosti kristala cakline na daljnje napade kiseline (27).

Amaechi i suradnici istraživali su učinak pasta za zube koje sadržavaju teobromin i NaF. Površinska mikrotvrdoća pokazala je značajnu remineralizaciju samo kada se upotrebljavala pasta za zube $s$ teobrominom. Iako se razina remineralizacije mogla usporediti, količina teobromina $(0,0011$ $\mathrm{mol} / \mathrm{L}$ ) potrebna za kariostatski učinak bila je 71 puta manja od količine fluora $(0,0789 \mathrm{~mol} / \mathrm{L})$ da bi se postigao usporediv učinak zubne paste. Zaključili su da teobromin pojačava remineralizaciju zbog svojstva stvaranja apatita u usporedbi sa zubnim pastama koje sadržavaju $\mathrm{NaF}(28)$.

Lippert (2017.) istraživao je učinak fluora, stroncija, teobromina i njihovih kombinacija na remineralizaciju karijesnih lezija u uvjetima $\mathrm{pH}$ cikliranja (29).

Kargül i suradnici promatrali su učinak teobromina na očuvanje površine cakline. Cilj ovoga istraživanja in vitro bio je ispitati učinkovitost obrade teobrominom na površinsku tvrdoću i topografiju ljudske cakline u dvjema različitim koncentracijama. Analiza mikrotvrdoće površine cakline na početku tretiranja teobrominom i nakon toga postupka pokazale su zaštitni učinak teobromina (24). Daljnja istraživanja na ljudskim zubima provedena su da bi se procijenilo kako je izloženost teobrominu modificirala površinu cakline in vitro $(24,28,30)$. Podupirući nalaze istraživanja in vitro, rezultati istraživanja in vivo pokazali su da je mikrotvrdoća površine cakline u skupini s teobrominom uvelike poboljšana u usporedbi sa skupinom u kojoj je promijenjen fluor (28).

Qasthari i suradnici (2018) istaknuli su da zubne paste koje sadržavaju teobromin bolje održavaju hrapavost površine cakline od onih s natrijevoim monofluorofosfatom (31).

$\mathrm{Ni} \mathrm{u}$ jednom dosadašnjem istraživanju autori nisu procijenili remineralizacijski potencijal pasta za zube koje sadržavaju teobromin s pomoću DIAGNOdenta. U ovom istra- 
No studies till date have evaluated the remineralization potential of theobromine containing toothpaste with DIAGNOdent. According to this study, the values decreased for both groups following remineralization. However, no significant difference was found between fluoride containing toothpastes and theobromine containing toothpastes.

This preliminary initiative of insight into the effects of theobromine in preventing ECC in pediatric population demonstrated that after one month of experimental period, there was no significant difference in the values of remineralization of fluoride and theobromine containing toothpaste assigned groups. However it would have been possible to observe a significant difference between the remineralization potentials of the two toothpastes, if a long term study had been conducted.

Several studies comparing theobromine and hydroxyapatite were also conducted and the following results were obtained: a study which aimed to analyze and compare the effects of toothpastes containing theobromine and hydroxyapatite on enamel microhardness has found that enamel microhardness was increased significantly after brushing with both Theodent (theobromine) and Pepsodent (HAP) toothpastes. However, the enhancement of enamel hardness in specimens treated with HAP-containing toothpaste was superior to those treated with theobromine toothpaste (32).

Toothbrushing is considered the most common oral hygiene habit. Oral hygiene is very important in protecting teeth against WSLs (33). The aim of modern dentistry is to manage initial caries lesions non-invasively through remineralization to prevent disease progression (34).

The contents of the toothpaste used have an impact on salivary functions and composition. Therefore, good toothpaste does not only contribute to remineralization directly, but also indirectly by enhancing the role of saliva in remineralization. Saliva is a major contributor to the protection of hard and soft intra oral tissues. Different properties of saliva such as facilitating the clearance of food, gathering and elimination of microorganisms, along with its buffering capacity to neutralize acids, contribute to remineralization of tooth enamel. Apart from that, saliva has antimicrobial properties. Therefore, salivary composition has been found to be associated with dental caries to varying degrees. Salivary properties can be used as biomarkers for indicating the risk of future disease and could potentially inform interference to deal with this risk (35).

The importance of caries preventative role of theobromine toothpaste by means of controlling S.mutans levels in saliva was evident compared to fluoride containing toothpastes. Chi et. al. assessed the results of toothbrushing with xylitol toothpaste in the prevention of ECC and the reduction of S.mutans. In the six month follow up, brushing with xylitol/fluoride toothpaste was found to be no more efficacious in reducing ECC than fluoride-only toothpaste in a high caries-risk child population (36). However, when Cakır et al. examined the antibacterial effect of Theodent Kids in an in vitro study, they found no antibacterial activity against $S$. mutans (37).

The primary outcomes of this short term follow up study were as follows: after 4 week use of theobromine contain- živanju vrijednosti su se nakon remineralizacije smanjile $u$ objema skupinama. No nije pronađena značajna razlika između pasta za zube koje sadržavaju fluor i onih s teobrominom.

Ovi preliminarni rezultati o učinku teobromina na sprječavanje karijesa u ranoj dječjoj dobi pokazali su da se nakon jednomjesečnog eksperimentalnog razdoblja nije dogodila značajna razlika u vrijednostima remineralizacije nakon primjene zubne paste s fluorom ili teobrominom. No mogla bi se uočiti značajna razlika između remineralizacijskih potencijala tih dviju pasta za zube da je provedeno dugoročno istraživanje.

Također je provedeno nekoliko istraživanja u kojima se uspoređuje teobromin i hidroksiapatit te su dobiveni sljedeći rezultati: u istraživanju čiji je cilj bio analizirati i usporediti učinak zubnih pasta koje sadržavaju teobromin i hidroksiapatit na mikrotvrdoću cakline otkriveno je da se mikrotvrdoća cakline značajno povećala nakon četkanja pastama Theodenta (teobromin) i Pepsodent (HAP). No povećanje tvrdoće cakline u uzorcima tretiranima zubnom pastom koja sadržava HAP bilo je veće nego u uzorcima tretiranima zubnom pastom $s$ teobrominom (32).

Četkanje zuba smatra se najučinkovitijom metodom oralne higijene. Oralna higijena vrlo je važna u zaštiti zuba od bijelih mrlja (33). Cilj suvremene dentalne medicine jest neinvazivno liječenje inicijalnih karijesnih lezija remineralizacijom kako bi se spriječilo napredovanje bolesti (34).

Sastojci korištene zubne paste utječe na funkciju i sastav sline. Zato dobra pasta za zube ne pridonosi samo izravno remineralizaciji, nego neizravno pojačava ulogu sline u remineralizaciji. Slina je glavni čimbenik koji pridonosi zaštiti tvrdih i mekih intraoralnih tkiva. Različita svojstva sline poput olakšavanja u čišcenju od hrane, skupljanja i uklanjanja mikroorganizama, zajedno s njezinim puferskim kapacitetom da neutralizira kiseline, pridonose remineralizaciji zubne cakline. Uz to, slina ima antimikrobna svojstva. Zato je utvrdeno da je sastav sline u različitom stupnju povezan sa zubnim karijesom. Svojstva sline mogu se upotrijebiti kao biomarkeri koji upozoravaju na rizik od budućih bolesti i mogu utjecati na upravljanje tim rizikom (35).

Važnost preventivne uloge teobrominske zubne paste u prevenciji karijesa s pomoću kontrole razine $S$. mutans u slini bila je očita u usporedbi sa zubnim pastama koje sadržavaju fluor. Chi i suradnici procijenili su rezultate četkanja zuba pastom za zilitol u prevenciji ECC-a i smanjenju $S$. mutans. U šestomjesečnom praćenju utvrđeno je da četkanje zubnom pastom sa ksilitolom/fluoridom nije djelotvornije u smanjenju ECC-a od zubne paste sa samo fluoridom u dječjoj populaciji s visokim rizikom od karijesa (36). No kada su Cakır i suradnici ispitivali antibakterijski učinak paste Theodent Kids u studiji in vitro, nisu otkrili antibakterijsko djelovanje na S. mutans (37).

Primarni ishodi ovoga kratkotrajnog praćenja bili su sljedeći: poslije četiri tjedna korištenja paste za zube s teobrominom značajno su se promijenili $\mathrm{pH}$ sline, puferski kapacitet i količina bakterije $S$. mutans. Dokazi pokazuju važnu ulogu teobromina u sprječavanju bakterija da stvaraju kiselinu, što zauzvrat povećava $\mathrm{pH}$ sline i narušava kiselinsku toleranciju kariogenih bakterija. Ta otkrića ističu protukariogene učinke povezane s oralnom bioraspoloživošću teobromina u zubnim pastama. 
ing toothpaste, salivary $\mathrm{pH}$, buffering capacity and S.mutans counts were significantly altered. The evidence reflects the important role of theobromine in impeding acid production by bacteria, which, in turn, increases salivary $\mathrm{pH}$ and disrupts the acid tolerance of cariogenic bacteria. These findings underline the anti-cariogenic effects associated with oral bioavailability of theobromine in toothpastes.

However, some limitations of our study are sample sizes of the groups and the F concentration of the control toothpaste. Therefore, this study is an observational study with results that deviate from the general failure patterns of the control group. Yet, being one of the first clinical studies on a novel toothpaste, we believe that the results of this study are worth noting.

\section{Conclusions}

The present study investigated the caries-preventive effect of Theobromine containing Toothpaste by examining its capacity for remineralizing caries lesions and inducing mineral deposition. The preliminary results suggest that theobromine containing toothpastes might be a choice for the prevention of ECC in children. There is still a clear need for further studies to investigate the mechanism by which theobromine induces mineral deposition and crystal growth, its potential advantages over other enamel protective compounds, its impacts on salivary composition, buffering capacity and clearance, and effects of long term theobromine administration.

This study can offer a novel toothpaste alternative to early childhood oral hygiene habits.

\section{Acknowledgement}

The authors would like to express their appreciation to Dr. H. Ralph Rawls and, Dr. Tetsuo Nakamoto for helpful discussions and cooperation.

\section{Conflicts of interest}

All authors declare that they have no conflicts of interest. This study was not supported by any grant or company.

\section{Statement of Ethics}

The study was reviewed and approved by The Human Research Ethics Committee of Yeditepe University, School of Medicine with the protocol number of 392.

Author's contribution: K.B., MA.D., B.G, P.K.Y. - have been involved in the design and planning of the study; M.A.D., P.K.Y. G.B., S.O. - have been involved in data collection; B.K., M.A.D. - have been involved in data analysis; B.K., M.A.D., P.K.Y.,B.G., S.O. - have been involved in data interpretation, drafting the manuscript and revising it critically, and have given the final approval of the version to be published. All authors have made substantial contributions to conception and design of the study.
Važnost preventivne uloge zubnih pasta koje sadržavaju teobromin u prevenciji karijesa kontrolom razine $S$. mutans u slini bila je očita u usporedbi sa zubnim pastama koje sadržavaju fluor. Chi i suradnici analizirali su rezultate četkanja zuba pastom sa ksilitolom u prevenciji karijesa u ranoj dječjoj dobi i smanjenju razine bakterije $S$. mutans. U šestomjesečnom praćenju ustanovili su da četkanje zubnom pastom sa ksilitolom/fluorom nije djelotvornije u smanjenju incidencije karijesa rane dječje dobi od zubne paste samo s fluorom u dječjoj populaciji s visokim rizikom od karijesa (36). No kada su Cakır i suradnici ispitivali antibakterijski učinak paste Theodent Kids u istraživanju in vitro, nisu otkrili antibakterijsko djelovanje na $S$. mutans (37).

Međutim, neka ograničenja u našem istraživanju su veličina uzorka u skupinama i koncentracija fluora u pasti za zube. Zato je to opservacijsko istraživanje $s$ rezultatima koji odstupaju od općih obrazaca neuspjeha u kontrolnoj skupini. Ipak, kako je riječ i o jednom od prvih kliničkih istraživanja nove zubne paste, pretpostavljamo da su rezultati ovog istraživanja vrijedni pozornosti.

\section{Zaključak}

U ovom istraživanju analiziran je karijesprotektivni učinak paste za zube koja sadržava teobromin mjerenjem njezina svojstva remineralizacije karijesnih lezija i poticanja taloženja minerala. Preliminarni rezultati sugeriraju da bi paste za zube $s$ teobrominom mogle biti dobar izbor za prevenciju karijesa u ranoj dječjoj dobi. Još uvijek postoji potreba za daljnjim istraživanjima kako bi se istražio mehanizam kojim teobromin potiče taloženje minerala i rast kristala, njegove potencijalne prednosti u odnosu prema ostalim spojevima koji imaju zaštitni učinak na caklinu, utjecaj na sastav sline, puferski kapacitet i klirens te učinak dugotrajne primjene teobromina.

Ovo istraživanje predlaže novu zubnu pastu kao alternativu u održavanju oralne higijene u ranom djetinjstvu.

\section{Zahvala}

Autori zahvaljuju dr. H. Ralphu Rawlsu i dr. Tetsuu Nakamotu na korisnim raspravama i suradnji.

\section{Sukob interesa}

Svi autori izjavljuju da nisu bili u sukobu interesa. Istraživanje nije financirano iz potpora ili sredstava tvrtki.

\section{Izjava o etičnosti}

Istraživanje je pregledao i odobrio Etički odbor za ljudska istraživanja Medicinskog fakulteta Sveučilišta Yeditepe (protokol broj 392).

Doprinos autora: K. B., M A. D., B. G, P.K .Y. - uključeni u dizajn i planiranje istraživanja; M. A. D., P. K. Y. G. B., S. O. - uključeni u prikupljanje podataka; B. K., M. A. D. - uključeni u analizu podataka; B. K., M. A .D., P. K. Y., B. G., S. O. - sudjelovali u interpretaciji podataka, izradi rukopisa i kritičkoj reviziji te dali konačno odobrenje za objavljivanje. Svi su autori znatno pridonijeli koncepciji i dizajnu istraživanja. 


\section{Sažetak}

Svrha rada: Učinci teobromina na remineralizaciju cakline privukli su pozornost kliničara. Cilj ovog istraživanja bio je istražiti karijesprotektivni učinak paste za zube koja sadržava teobromin na karijes u ranoj dječjoj dobi. Materijal i metode: Izmjereni su pH sline, puferski kapacitet i razina bakterija Streptococcus mutans. Svakom djetetu dodijeljena je zubna pasta s fluorom ili teobrominom. Promjene su analizirane s pomoću laserskoga fluorescentnog sustava. Obavljene su statističke analize. Rezultati: U skupinu s fluoriranom zubnom pastom (Colgate Kids) bilo je uključeno 13 djece (prosječna dob 4,25) sa 145 zuba; u skupini sa zubnom pastom koja sadržava teobromin (TheodentTMKids) sudjelovalo je 13 djece (prosječna dob 4,46) sa 115 zuba. Obje zubne paste potaknule su remineralizaciju cakline i učinkovito su povećale puferski kapacitet i $\mathrm{pH}(\mathrm{p}<0,05)$. U objema skupinama ustanovljeno je statistički značajno smanjenje razine $S$. mutans $(p<0,05)$. Zaključak: Obje zubne paste imale su statistički značajan učinak na remineralizaciju cakline. Budući da su kod teobromina zabilježene dodatne prednosti poput povećanja $\mathrm{pH}$ sline i smanjenja razine S. mutans, paste za zube koje sadržavaju teobromin mogu se smatrati učinkovitim sredstvom za remineralizacije bijelih mrlja i mogu se upotrebljavati u prevenciji ranih lezija cakline.
Zaprimljen: 16. rujna 2020.

Prihvaćen: 25. siječnja 2021.

Adresa za dopisivanje

Müesser Ahu DURHAN

ORCID: 0000-0002-0605-1250

Marmara University, Faculty of

Dentistry

Department of Paediatric Dentistry

Maltepe, Basibuyuk Saglik Kampusu,

34854, Istanbul, Turkey

tel. 0090-5052451178

ahudurhan@hotmail.com

MeSH pojmovi: zubne paste; teobromin; remineralizacija zuba; preventivna stomatologija; dijete predškolske dobi

\section{References}

1. Tadic K, Katic V, Spalj S. Caries Experience of the Patients Referred for an Orthodontic Consultation. Acta Stomatol Croat 2018;52(2):123-31

2. Karaca S, Ozbay G, B. K. Primary Zirconia Crown Restorations for Children with Early Childhood Caries. Acta stomatologica Croatica 2013;47:64-71.

3. Anil S, Anand PS. Early Childhood Caries: Prevalence, Risk Factors, and Prevention. Front Pediatr. 2017 Jul 18;5:157.

4. Walsh T, Worthington HV, Glenny AM, Marinho VC, Jeroncic A. Fluoride toothpastes of different concentrations for preventing dental caries. Cochrane Database Syst Rev. 2019 Mar 4;3(3):CD007868.

5. H. Limeback, Robinson C. Fluoride therapy. Hoboken, NY, USA: John Wiley \& Sons; 2012.

6. Marinho VC, Worthington HV, Walsh T, Chong LY. Fluoride gels for preventing dental caries in children and adolescents. Cochrane Database Syst Rev. 2015 Jun 15;2015(6):CD002280.

7. Meyer F, Enax J. Early Childhood Caries: Epidemiology, Aetiology, and Prevention. Int J Dent. 2018 May 22;2018:1415873.

8. Dorozhkin SV. Calcium orthophosphates (CaPo4) and dentistry. Bioceramics Development and Applications 2016;6(96).

9. Gustafsson BE, Quensel CE, Lanke LS. The Vipeholm dental caries study; the effect of different levels of carbohydrate intake on caries activity in 436 individuals observed for five years. Acta Odontol Scand 1954;11(3-4):232-64.

10. Stralfors A. Effect on hamster caries by dialysed, detanned or carbon-treated water-extract of cocoa. Arch Oral Biol 1966;11(6):609-15

11. Stralfors A. Inhibition of hamster caries by cocoa. Caries inhibition of water and alcohol extracts of cocoa. Arch Oral Biol 1966;11(3):323-8.

12. Stralfors A. Inhibition of hamster caries by cocoa. The effect of whole and defatted cocoa, and the absence of activity in cocoa fat. Arch Oral Biol 1966;11(2):149-61.

13. Stralfors A. Inhibition of hamster caries by substances in chocolate. Arch Oral Biol 1967;12(8):959-62.

14. Stralfors $A$. Effect on hamster caries by purine derivatives vanillin and some tannin-containing materials. Caries in relation to food consumption and animal growth. Arch Oral Biol 1967;12(3):32132.

15. Falster AU, Yoshino S, Hashimoto K, et al. The effect of prenatal caffeine exposure on the enamel surface of the first molars of newborn rats. Arch Oral Biol 1993;38(5):441-7.

16. Nakamoto T, Cheuk SL, Yoshino S, Falster AU, Simmons WB. Cariogenic effect of caffeine intake during lactation on first molars of newborn rats. Arch Oral Biol 1993;38(10):919-22.

17. Falster AU, Hashimoto K, Nakamoto T, Simmons WB. Physical examination of caffeine's effects on the enamel surface of first molar in new-born rats. Arch Oral Biol. 1992 Feb;37(2):111-8.

18. Farah A, Donangelo C. Phenolic compounds in coffee. Brazilian Journal of Plant Physiology 2006;18(1):23-26.

19. MeSH Browser [database on the Internet]. Nakamoto T, Simmons WB Jr, AU F. Products of Apatite-Forming Systems. US Patent ap plication number: US 5,919,426:. http://patft.uspto.gov/netac$\mathrm{gi} / \mathrm{nph}$-ParserSect $2=$ PTO1\&Sect $2=$ HITOFF $\& \mathrm{p}=1 \& \mathrm{u}=/$ netaht $\mathrm{ml} / \mathrm{PTO} /$ search-bool.html\&r=1\&f=G\&l=50\&d=PALL\&RefSrch $=$ yes\&Query $=$ PN/5919426. 1999 .
20. MeSH Browser [database on the Internet]. Nakamoto T, Simmons WB Ir, AU F. Apatite-Forming Systems: Methods and Products.US Patent application number: US 6,183,711B1 http://patft.uspto. gov $/$ netacgi $/$ nphParser?Sect2 = PTO1\&Sect2 = HITOFF \&p =1\&u $=/$ netahtml/PTO/search-bool.html\&r $=1 \& \mathrm{f}=\mathrm{G} \& \mathrm{l}=50 \& \mathrm{~d}=$ PALL\&RefSrch = yes $\&$-Query $=$ PN/6183711. 2001.

21. MeSH Browser [database on the Internet]. Sadeghpour A, T $\mathrm{N}$. Methods and Compositions o Improve Mechanical Resistance of Teeth. International Patent application number: PCT/ US2011/024734;: http://patentscope.wipo.int/search/en/ W02011100671 2011.

22. Wulandari N, Irawan B, Herda E. Effects of theobromine toothpaste on prevention of enamel discoloration from coffee Journal of Physics: Conf. Series 10732018.

23. Malisoff W. Dictionary of biochemistry and related subjects. New York: Philosophical Library; 1943.

24. Kargul B, Ozcan M, Peker S. Evaluation of human enamel surfaces treated with theobromine: a pilot study. Oral Health Prev Dent. 2012;10(3):275-82.

25. Ismail Al, Sohn W, Tellez M. The International Caries Detection and Assessment System (ICDAS): an integrated system for measuring dental caries. Community Dent Oral Epidemiol 2007;35(3):170-8.

26. Lussi A, Hibst R, Paulus R. DIAGNOdent: an optical method for caries detection. J Dent Res 2004;83 Spec No C:C80-3.

27. ten Cate JM, Timmer K, Shariati M, Featherstone JD. Effect of timing of fluoride treatment on enamel de- and remineralization in vitro: a pH-cycling study. Caries Res 1988;22(1):20-6.

28. Amaechi BT, Porteous N, Ramalingam K, et al. Remineralization of artificial enamel lesions by theobromine. Caries Res 2013;47(5):399-405.

29. Lippert F. The effects of fluoride, strontium, theobromine and their combinations on caries lesion rehardening and fluoridation. Arch Oral Biol 2017;80:217-21.

30. Taneja V, Nekkanti S, Gupta K, Hassija J. Remineralization Potential of Theobromine on Artificial Carious Lesions. I Int Soc Prev Community Dent. 2019 Nov 4;9(6):576-583.

31. Qasthari A I, Irawan B, Herda E. The influence of brushing with theobromine and sodium monofluorophosphate toothpaste on enamel surface resistance to roughness after demineralization Journal of Physics: Conf. Series 10732018.

32. M Suryana, B Irawan, Soufyan A. The Effects of Toothpastes Containing Theobromine and Hydroxyapatite on Enamel Microhardness after Immersion in Carbonated Drink IOP Conf. Series: Journal of Physics: Conf. Series 2018.

33. Khoroushi M, Kachuie M. Prevention and Treatment of White Spot Lesions in Orthodontic Patients. Contemp Clin Dent. Jan-Mar 2017;8(1):11-19.

34. Cochrane NJ, Cai F, Huq NL, Burrow MF, Reynolds EC. New approaches to enhanced remineralization of tooth enamel. J Dent Res. 2010 Nov;89(11):1187-97.

35. Lalloo R, Tadakamadla SK, Kroon J. Salivary characteristics and dental caries experience in remote Indigenous children in Australia: a cross-sectional study. BMC Oral Health 2019;19(1):21.

36. Chi DL, Tut O, Milgrom P. Cluster-randomized xylitol toothpaste trial for early childhood caries prevention. J Dent Child (Chic). JanApr 2014;81(1):27-32.

37. Cakir B, Eden E, Turan E. Evaluation of Antibacterial Effect of Toothpastes with Different Contents: An In Vitro Study Aydın Dental 2017;3(2):13-22. 